\title{
Beyond Populism Studies
}

\author{
Benjamin De Cleen and Jason Glynos \\ Vrije Universiteit Brussel / University of Essex
}

(Accepted for publication in the Journal of Language and Politics)

Ref: De Cleen, B. and Glynos, J. (2021) 'Beyond Populism Studies’, Journal of Language and Politics 20(1).

http://doi.org/10.1075/jlp.20044.dec

\begin{abstract}
'Populism' has become ever more ubiquitous in political analysis, to the extent that 'populism studies' appears on course to establishing itself as a field of research in its own right. This article warns about the dangers of such a development. Taking a discourse theoretical approach as our starting point - but also critically engaging with this tradition's contribution to the hype about populism - we suggest that 'populism studies' (and the preoccupation with populism this field embodies) risks reifying populism by focusing on populism as a phenomenon 'as such', and through an over-reliance on the concept of populism to approach that phenomenon. This, we argue, hampers a nuanced and contextualized understanding of the exact role populism plays in different populist politics. This is not a call for abandoning the concept of populism altogether, but a call for decentring the concept and for moving beyond academia's 'populist moment'.
\end{abstract}

Keywords: Populism, discourse theory, populism studies

\section{Introduction}

A spectre is haunting the academy - the spectre of populism. It is not the spectre of populist politics per se that interests us here (as in Ionescu and Gellner's 1969 seminal volume on populism), but the spectre of 'populism' as an ever more ubiquitous label in political analysis and beyond. This 'turn to populism' is not only a turn towards populist politics as an object of enquiry but also a turn towards populism as a framework of analysis.

Academic reflections on populism are anything but new, but the concept has taken up an ever more central role, and the number of conferences and publications on populism has skyrocketed. Populism now even has its own journals. Founded in 2018, for example, the journal Populism is "devoted to promoting transdisciplinary examination of populism in both historical and 
contemporary contexts"'. 'Populism studies', it seems, is on course to establishing itself as a field of research in its own right.

In this piece we draw attention to the downsides associated with the development of 'populism studies', and to the broader colonization of political analysis by the concept of populism, of which 'populism studies' is the clearest illustration. We do not question that populism is an important dimension of contemporary politics and that the concept of populism has a role to play in political analysis - especially now that advances in the conceptualization of populism have turned it into a much sharper tool of analysis. But we believe that turning populism into the focal point of analysis to the degree it has comes with serious risks. We warn especially against the reification of populism as a phenomenon per se and against the strong or even exclusive reliance on the concept of populism as an analytical framework.

We sense that certain kinds of work on populism but also the sheer volume of it are being met by many colleagues with increasing fatigue, impatience, and frustration. We are by no means the first to caution against a problematic preoccupation with populism (e.g. Cannon 2018; Collovald 2004; Dean and Maiguashca 2020; Maiguashca 2019; Rydgren 2017) or to stress the need to link the study of populism to other literatures and areas of specialization (Mudde and Rovira Kaltwasser 2018; Rooduijn 2019). But we do feel it is worth spelling out more explicitly the problems associated with the focus on populism in its own right as well as the implications of such a diagnosis for the field of 'populism studies' and the study of populism more broadly.

In making our claim we draw on a poststructuralist discourse theoretical approach (Laclau and Mouffe 1985), but we also critically engage with tendencies in this tradition to put populism centre stage (e.g. Laclau 2005a, 2005b; Mouffe 2018). Arguing against these tendencies, we suggest that the discourse theoretical focus on the articulation of demands encourages us to approach populist politics differently than through the prism of populism alone. It also draws our attention to the performative effects of discourses about populism. In concluding, we highlight what kinds of engagement with populism might characterize a move 'beyond' populism studies.

\section{The Paradox of Populism Studies: The Unfulfilled Promise of Minimal Definitions}

There is no denying that populism has taken on a prominent role in contemporary politics, and this seems unlikely to change anytime soon. In this context the growth in studies that take seriously the populist dimension of politics makes perfect sense and is welcome. Moreover, the surge of work on populism has done much to sharpen populism as a conceptual tool. Significant (and inescapable) disagreements on the nature and normative evaluation of populism notwithstanding, the study of populism has to a large extent converged around a number of 'minimal' definitions of populism (even if 'thicker' definitions also remain in play).

These minimal definitions consider populist politics to be characterized by the opposition between 'the people' and 'the elite' - with populists claiming to speak in the name of 'the people' and against the illegitimacy of a present elite that does not represent 'the people' - whilst bracketing other

\footnotetext{
${ }^{1}$ https://brill.com/view/journals/popu/popu-overview.xml
} 
elements that characterize certain populist politics (e.g. nativism, particular socio-economic policies, strong personalized leadership). These minimal definitions have removed the association between populism and particular ideational or organizational factors typical of earlier (and some current) academic work on populism and still very present in journalism and political discourse. Minimal definitions have major benefits in that they make the concept of populism relevant for the analysis of a wide range of populist politics across the political spectrum, whilst at the same time capturing the specificity of populism and delineating it from other concepts such as nationalism and authoritarianism.

The most prominent 'minimal' definition is associated with the 'thin ideology' or 'ideational' approach. Populism is defined here as "a thin-centered ideology that considers society to be ultimately separated into two homogeneous and antagonistic camps, 'the pure people' versus 'the corrupt elite,' and which argues that politics should be an expression of the volonté générale (general will) of the people" (Mudde and Rovira Kaltwasser 2017, 6). Cas Mudde and Cristóbal Rovira Kaltwasser, two of the central figures associated with this approach, have stressed that populism in itself "can offer neither complex nor comprehensive answers to the political questions that modern societies generate" and "necessarily appears attached to - and sometimes is even assimilated into - other ideologies" (Mudde and Rovira Kaltwasser 2017, 6; 2018). ${ }^{2}$

Another prominent attempt to identify the specificity of populism has been produced from within the discourse theoretical tradition. This approach is more formal and discursive (rather than ideational) in nature. It focuses on how populist politics discursively construct 'the people' as an underdog against 'the elite', which is perceived as illegitimate, through the articulation of different demands and identities that are (said to be) frustrated by 'the elite' into a chain of equivalence symbolized by the signifier 'the people' (Laclau 1977, 2005a, 2005b; Stavrakakis and Katsambekis 2014; De Cleen and Stavrakakis 2017).

Significant conceptual and normative differences between these two approaches (see below) notwithstanding, both of these minimal definitions of populism suggest that populism is only ever a particular dimension of otherwise widely varying politics, and that the populist dimension of such politics needs to be considered in relation to other aspects, in analytical as well as normative terms.

What interests us here is that these sorts of considerations - which we very much agree are crucial - have not resulted in less talk about populism. If anything, whilst clearly stating that populism is only ever one dimension of populist politics, attempts to arrive at a sharp definition and to counter sweeping uses of the term have also contributed to the abundant academic production of works conceptualising and reconceptualising populism, thereby also contributing to the development of 'populism studies'. Moreover, whilst in many cases warning against imprecisions and exaggerations, researchers who study populism have also benefited from such imprecisions and from the heightened journalistic and political interest in (and panic about) populism - increasing,

\footnotetext{
${ }^{2}$ Michael Freeden, who coined the term 'thin ideology' and used it to characterise green ideology and nationalism, has been critical of its application to populism writing that "[a] thin-centred ideology implies that there is potentially more than the centre, but the populist core is all there is; it is not a potential centre for something broader or more inclusive. It is emaciatedly thin rather than thin-centred." (Freeden 2017, 3) Freeden also argues that populism does not even have 'the potential to become full' (Freeden 2017, 3; emphasis added).
} 
as it has, the visibility of their work, and the funding for populism research (Cannon 2018). A growing and welcome consensus on the need for a precise definition of populism, understood as a particular dimension of certain kinds of politics, has thus paradoxically gone hand in hand with the development of an expansive and still-expanding field of 'populism studies' that - in certain kinds of work but also through its very existence as a field of study - seems to take no heed of the modesty that is in fact implied by such minimal definitions.

Minimal definitions of populism focused on the people/elite distinction and the claim to represent 'the people' form a good basis for identifying populist politics and for capturing their populist dimension. And this is no small feat. However, such minimal definitions cannot do much more than that. They cannot, in themselves, grasp the specificity of particular populist politics, nor explain their prominence, nor evaluate them normatively in any conclusive manner.

This is why organizing work around the notion of populism - as captured most clearly by a field called 'populism studies' - harbours important risks, to which we now turn. It is also why we think that taking minimal definitions of populism to their logical conclusions implies a move 'beyond populism studies', as we will argue in the concluding section.

\section{Against the Reification of Populism}

Our general claim is that the study of populism has contributed to an undesirable reification of populism. With the term reification we aim to capture how the discursive construct 'populism' comes to be regarded as a 'thing' in itself and even as the driver of social and political developments. In the study of populism, the problem of reification manifests itself in two main ways: treating populism as a phenomenon 'as such' (rather than as a dimension of certain sorts of politics); and relying predominantly on the concept of populism to elucidate, diagnose and indeed explain that very phenomenon (rather than through a more systematic reference to notions other than populism). The clearest illustration of this tendency towards the reification of populism in these two ways is the ongoing establishment of a field called 'populism studies', but our argument also extends beyond that.

Going against seductions of creating a domain called 'populism studies', we suggest that 'populism' should be seen as a modest concept and as an analytical and normative 'entry point' rather than an endpoint or a focus in itself. In making this argument we build on discourse theory, which has played a significant role in arriving at a more precise definition of populism, as well as in correcting the dominant negative normative evaluation of populism. At the same time, discourse theory has itself also contributed to the hype about populism, and has also sometimes seen populism per se as inherently positive in a normative sense. Our argument, therefore, also turns discourse theoretical resources against certain tendencies within discourse theoretical work in an attempt to 'put populism in its right place', so to speak.

There are two main steps in our argument. First, building on discourse theory's insistence on the centrality of articulation in political practice, and particularly in populist politics, we argue against the reification of populism as the analytical focus and explanatory nucleus of 'populism studies'. 
Secondly, turning our attention to populism as a signifier, we reflect on the performative effects of discourses about populism, including the establishment of 'populism studies'.

\section{Countering Reification 1: Against Populism as Analytical Focus and Explanatory Nucleus}

How can a discourse theoretical approach to populism prevent the reification of populism as its analytical focus and explanatory nucleus, whilst at the same time resisting the equally problematic tendency of reducing populism to a mere symptom of broader socio-economic and socio-cultural crises? Which reification problems has discourse theoretical work itself exhibited? And how can we move beyond these problems?

The decisive step in discourse theoretical work on populism has been to approach populism as a political logic that discursively structures the political field in a particular way. This shifts the focus from the 'contents' of populism - what are the demands formulated by populist actors; what is their ideology? - to how it articulates "those contents - whatever those contents are" (Laclau 2005b, 33). Populism is theorized here in formal terms, as a way of formulating and bringing together ('articulating') political demands, and of interpellating subjects. The specificity of populism lies in how it revolves around "a down/up antagonism in which 'the people' is discursively constructed as a large powerless group through opposition to 'the elite' conceived as a small and illegitimate powerful group. Populist politics thus claim to represent 'the people' against an 'elite' that frustrates their legitimate demands, and presents these demands as expressions of the will of 'the people"' (Stavrakakis and De Cleen 2017, 310; see Laclau 2005a).

This gives the definition of populism a level of abstraction and formal precision that enables us to identify a variety of populisms across the political spectrum. Looking at populism as a political logic also turns our attention to the political work done through populist politics. Indeed, Laclau's early work on populism already signalled a clear effort to develop a political riposte to the socioeconomically determinist perspectives on populism dominant in the Latin American context (Laclau 1977), tendencies that are still present in explanations of populism, which present it as a mere symptom of socio-economic or socio-cultural conditions. The discourse theoretical approach also stresses the strategic dimension of populism and therefore also its temporary and fragile character (but without reducing demands and identities or even a 'turn to populism' itself to fully conscious and intentional actions by political agents). Political actors can turn to populism in a particular context, but might also let go of that populism or give it a less central role when the context changes (see for example Podemos' trajectory).

The notion that populist politics bring together (or articulate) different demands and sectors of society in opposition to 'the elite', we believe, implies a shift away from discussions of populism per se to the analysis of what demands are brought together, how, and in what context. That is to say, the judgement that a political leader, movement, or party performs a populist logic is but one element in critical political analysis and, from a normative and ideological perspective, certainly never enough.

Discourse theory's formal approach to populism therefore carries a powerful analytical message whose paradoxical character should not be missed. Yes, it is important to be clear about what we 
mean by populism, but having arrived at that clarity, the conclusion needs to be that this is only a starting point for analysis. A discursive approach to populism thus 'solves' the first aspect of the reification problem by turning populism into a 'vanishing mediator' that reveals to us that the relevant issues lie not only in populism as such, but also elsewhere, in the normative stakes of particular populist politics as well as the broader conditions within which the populist political logic operates and to which it contributes.

In this sense, a discourse theoretical approach is better able - at least potentially, as we discuss below - to avoid reification tendencies than the other major minimal definition associated with the thin ideology approach. We very much agree with the intuition underlying the ideational approach that the 'thin' populist dimension is always combined with other programmatic elements. However, thin ideology approaches still tend to attribute a priori substantive content to populist politics, however minimal this might be, and have in this manner contributed to the reification of populism. For one, the ideational definition implies a belief in populist ideas as the (at least partial) ideological basis for why populist political actors do what they do. It has also underpinned survey research that aims to measure 'populist attitudes' among electorates, thus zooming in on a belief in the populist ideology (typically opposed to a belief in pluralism and elitism) as the motivation for voting for populist parties (e.g. Akkerman et al. 2014). Moreover, the view of populist ideology as antipluralist underlies the claim that populism itself is a threat to liberal democracy (even if Mudde and others have also stressed that nativism and authoritarianism are the prime dangers to democracy, e.g. Akkerman 2017; Mudde 2017a, 2017 b). All of this has made the thin ideology approach simultaneously a powerful antidote to imprecise or sweeping uses of the term populism and a major contributor to the development of a brand of populism studies that focuses very much on populism per se as a normative and explanatory nucleus. It should be stressed here that recent explicit reflections on how to develop populism research by some of the authors associated with the thin ideology approach seem to respond to a similar intuition (e.g. Mudde and Rovira Kaltwasser 2018; Rooduijn 2019).

Discourse theory, with its formal rather than ideological view of populism, may have the theoretical resources to avoid this kind of reification, but this does not mean it has avoided it in practice. Discourse theory has certainly played its part in turning populism per se into a central issue in both the analytical and normative sense. It is noteworthy that 'the populist moment' - and especially the rise of left-wing populist actors such as Podemos, SYRIZA and Bernie Sanders was very much welcomed by scholars within the tradition. It aligned political reality in Europe and the US with one of the tradition's main research foci, thus proving the significance of the approach (not least because some left-wing populists declared having been inspired by Laclau's work or, like Jean-Luc Mélenchon and Podemos’ Ínigo Errejón, worked with Mouffe). These developments also chimed with the political-programmatic efforts to reinvigorate the left that have always figured prominently in discourse theory. None of this is problematic in itself, of course, but, if we want to avoid reifying or hyping populism, it does call for an increased awareness on our part, as discourse theorists, about the attention we give to populism and about how we deal with populism. We can highlight three 'reification worries' in discourse theory that, in our view, merit attention.

\footnotetext{
${ }^{3}$ For a different use of this notion see Stavrakakis et al. 2016 on the populist leader as a 'vanishing mediator'.
} 
The first reification worry emerges on account of discourse theory's focus on the populist logic as a logic of articulating demands. This has led it to pay much less attention to where those demands come from. This kind of focus on the articulation of demands (rather than on the genesis and content of those demands) already characterized Laclau and Mouffe's (1985) Hegemony and Socialist Strategy. Analytical reflection sometimes appears to start from (after, so to speak) the existence of frustrated demands, and tends to focus on the moment of articulation and on the (populist) political actors doing the articulating. Demands, as the basic unit of analysis, have therefore sometimes been treated a bit like a black box. In more political programmatic work this has sometimes led to seeing populism as such as the solution for the Left, at the expense of a more nuanced reflection on where 'frustrated demands' come from, or what kind of demands the left should pursue (e.g. Mouffe 2018).

One way to avoid the reification of demands is to stress, rather more so than Laclau or Mouffe themselves have tended to do, that populist politics do not merely bring existing frustrated demands together in a chain of equivalence against an 'administrative system' or 'power bloc' (Laclau 2005b, 37-40; see also Mouffe 2018). Populist politics also discursively co-construct such demands as well as the frustration with and illegitimacy of the 'elite' and the 'crisis of representation' (see Stanley 2008: 98; Moffitt 2015). In this sense, discourse theoretical work on populism can, with the theoretical resources already at its disposal, become more constructivist. Simultaneously, analyses of populism benefit from being embedded in thicker and more systematic empirical reflections on the ideological traditions of populist actors (e.g. the radical right or the radical left), on the particular social, economic and cultural structural conditions within which demands are formed (without however resorting to a socio-economic or other form of determinism that would go against the very ontological principles of discourse theory), and in broader reflections on the decline of traditional parties and intermediaries, ideological dedifferentiation, etc. (to which Mouffe's work has made major contributions).

The second reification worry emerges when populism becomes a synonym for 'the political'. In his later work, Laclau argues that populism is the "the royal road to understanding something about the ontological constitution of the political as such" (2005a, 67). This is so, according to Laclau, because populism revolves very strongly around the logic of equivalence, dividing the social space into two opposing camps (Laclau 2005a; see Thomassen 2016, 16) - a process distinguished from forms of 'government' or 'administration' that operate according to the logic of difference (Laclau and Mouffe 1985, xiii). The populist construction of 'the people' is seen as "the political act par excellence" (Laclau 2005a, 48) and positively valued in comparison to its opposites (technocracy, post-politics, consensus politics, etc.). One problem here is that 'populism' becomes the overarching label for any kind of politics that revolves around the logic of equivalence, antagonism, and conflict, which does not do populism's analytical precision much good. A related risk is that such analyses performatively contribute to the reification of the populism-versus-anti-populism opposition as the political frontier governing contemporary politics (see the next section).

Here again, however, discourse theory's conceptual apparatus allows a more modest conceptualization of populism. The focus on articulation invites detailed analyses of what kind of demands are brought together, how and in what context. Moreover, the understanding of populism as a way of constructing a particular political frontier that emphasises the (vertical) down- 
up relation between people and elite, not just their antagonistic relation - a position apparent in Laclau's earlier work and in some parts of his later work (see Laclau 2005b, 38-40) - highlights the specificities of populism and its interaction with other political logics (on populism and nationalism, see Anastasiou 2019; De Cleen and Stavrakakis 2017; De Cleen 2017). This more precise and modest definition also makes it apparent that the concept of populism can play a (modest) role in the analysis of political struggles in less polarized contexts (i.e., with fewer opportunities for constructing broad chains of equivalence) that might be far removed from the kind of, mainly Latin American, politics that inspired Laclau's work on populism.

The third reification worry has to do with the way populism is evaluated normatively. Work based on discourse theory has done an important job in correcting the overly negative view of populism, and in going against the tendency to treat the label 'populism' as a normative analysis in itself (as is apparent in the populism-versus-pluralism schema). But discourse theoretical work has also gone further than merely uncoupling populism from its negative connotations by stressing its inherent democratizing effects and, sometimes, also underplaying problematic aspects of particular populist politics (see Zuquete 2018). Here, some discourse theoretical work too risks making populism the endpoint of normative reflections - in this case: a good thing in itself and the solution to democracy's problems - rather than the starting point for nuanced normative evaluation of actually existing populist politics.

This tendency is connected to the above-noted inclination to treat populism as the embodiment of 'the political' par excellence. This way of thinking tends to attribute a positive normative valence to populism per se as the democratising moment of politics. This outlook underlies Mouffe's insistence that our 'populist moment', with populisms on both the left and the right, is a matter of "resistances against the post-political consensus" (Mouffe 2018, 12). This is an argument that focuses very much on populism per se, a fact that becomes particularly visible in Mouffe's 2018 book For a Left Populism, in which she talks rather more of the need for the left to develop a populist strategy than about the content of such a left-wing project. Moreover, in some passages she appears to recognize, based on a populism-versus-neoliberal post-democracy framework, the 'democratic' nature of some radical right demands as "demands of the popular sectors who felt excluded from the dominant consensus" that were "translate[d] into nationalist vocabulary" by radical right parties (Mouffe 2018, 19). Generally, however, scholars working with discourse theory have tended to focus more on the left populisms they sympathize with, sometimes even explicitly reserving the term populism for left-wing projects whilst questioning whether the populist radical right is populist at all (e.g. Stavrakakis et al. 2017a).

Stressing the positive normative dimensions of populism has been an understandable and valid tendency. However, taking this too far is a move that has downsides both analytically (e.g., by potentially underplaying the importance of populism to the radical right, for example) and normatively (e.g., by partially blinding analysts to the serious problems with many populist politics, including left populisms; and by making 'populism' the endpoint of normative considerations). 


\section{Countering Reification 2: Interrogating Populism as Signifier}

We now shift our attention to the performative effects of discourses about populism in reifying populism and in producing a field of populism studies with its associated problems. Discourse theory - with its focus on the role of signification in politics and society - draws our attention to discourses about populism as themselves implicated in the political struggles they analyse and comment on; and, therefore, as themselves worthy of critical inquiry (see Stavrakakis 2017a).

As the notion of populism became ever more ubiquitous across political, journalistic and academic discourse, critical reflections on the use of the notion have become more common. Much of this work has delivered a normative and political critique of the pejorative use of the term populism. A major point of contention has been that mainstream anti-populism constitutes a defence of a problematic status quo that lumps together left-wing and right-wing populist alternatives as one single threat to liberal democracy (e.g. Cannon 2018, 486; D’Eramo 2013; Jäger 2017; Katsambekis 2017; Stavrakakis et al. 2017, 2018). Others have argued that, even if the term populism is used in a derogatory fashion, discussing the radical right in terms of populism has turned attention away from these parties' nativism and authoritarianism (see Mudde 2017a, 2017b; Rydgren 2017), and has sometimes inadvertently confirmed the radical right's claim that they are indeed 'the representative of the people' (De Cleen et al. forthcoming; Mondon 2017).

However, to understand the dynamics behind the ubiquity of discourses about populism as well the performative effects of such discourses, we also need to look beyond normative intentions, paying more attention to the dynamics of the academic debate about populism and its relation to media and politics. This shifts our attention to the performative effects of the focus on populism per se. The main point here is that beyond strong disagreements about the democratic desirability and the precise nature of populism, 'populism studies' and debates about populism more broadly have converged around the centrality of populism in our understanding of the current political moment. Indeed, if anything, strong normative disagreements about populism have driven the expanding production of discourses about populism and have strengthened the centrality of populism in debate and analysis. Beyond normative disagreement, the production of academic work on populism has also been strengthened by other factors such as publication opportunities, funding, visibility and a bandwagon effect.

Not much attention has been paid to such dynamics underlying and perpetuating debates about populism. Still, there have been a number of interventions reflecting on the character, intensity, and significance of the performative effects of discourses about populism in politics, media and academia, even if these have not been developed in any detail (e.g. Cannon 2018; Dean and Maiguashca 2020; De Cleen et al. 2018; Glynos and Mondon 2016; Rydgren 2017; Stavrakakis 2017a). For example, Jäger (2017) and Stavrakakis (2017b) refer to Anthony Giddens' concept of double hermeneutics which highlights how "[s]ocial scientists [...] tend to shape the very objects they propound to observe" (Jäger 2017, 13), their concepts impacting on the self-understandings, discourses and practices in that society. These then feed into academic reflections on, and analyses of, societal discourses and practices that have integrated academic reflections and concepts. Jäger and Stavrakakis use this notion to point out how the negative connotation of populism in academic work and in the political and media spheres are connected. However, this notion of double 
hermeneutics could also be used to think more broadly about how the ubiquity of the concept of populism itself - beyond the normative valence attached to populism - feeds into and has become implicated in wider mediatic and political dynamics. Like the notions of populist hype (Glynos and Mondon 2016) and 'speculative bubble' (Csigó 2016), this highlights how all producers of discourses about populism operate in a house of mirrors, where academics, politicians, and journalists reflect and further reinforce each other's focus on populism (see Goyvaerts and De Cleen 2020).

Our point is that all positions in populism studies and the populism debate more broadly - to the extent that they foreground populism - have contributed to the growing dominance of the concept of populism and to a populist/anti-populist reading of the current political conjuncture. This also leads to the formulation of populist and anti-populist strategies based on that reading, which strengthen the populist/anti-populist cleavage, and are then, again, interpreted through the lens of (anti-)(anti-)populism. Whilst the awareness of the normative significance of discourses about populism is already very high among critical approaches to populism, paying more attention to wider dynamics that go beyond the normative appreciation of populism would help to guard against some of the reification risks associated with a focus on populism.

\section{Conclusion: Beyond Populism Studies}

With this article we have sought to critically interrogate some of the risks and limitations of a field of populism studies, as well as of the broader colonization of political analysis by populism - as phenomenon and conceptual framework - this field most clearly symbolizes. We have formulated our argument in terms of a need to move 'beyond populism studies'. But what does such a move imply?

We start with the most straightforward interpretation and message of our article: a call for studies of populism to move beyond a narrow focus on populism. Moving 'beyond' populism studies in this sense means that studies of populism should not focus solely on the populist dimension of the populist politics they study, instead broadening the analysis to include how populism relates to other dimensions (nationalism, socialism, conservatism, etc.) and to the wider political, cultural, economic and social context within which they operate (see Rooduijn 2019). This also implies that populism be treated as a useful but modest concept that needs to be integrated into a broader conceptual framework, the precise ingredients of which depend on the characteristics of the populist politics under study and the nature of the research questions asked. Much work on populism - discourse theoretical and otherwise - it should be stressed, already moves beyond populism in the way described here.

Work on populism has also moved beyond populism populism in another way. A growing awareness of the performative effects of discourses about populism has led to work on populism that encompasses reflections on how discourses about populism in media, journalism, and academia are implicated in the political reality they describe. Such work has mainly been concerned with the ideological positions implied in discourses about populism and the normative judgementalism this gives rise to. To this, we have argued, should be added an awareness of how 
all discourses about populism, whatever their ideological implications, are involved in a debate that has performative effects that escape ideological intentions.

A move beyond populism in these two ways (including dimensions other than the populist one and including meta-reflections on discourses about populism), however, does not entirely dissolve the risks of reification associated with the establishment of a field of populism studies per se (or with the focus on populism more broadly). This is because the very establishment of such a field implies the organization of academic work and debate around populism, as empirical focus and as analytical framework. Indeed, it can be argued that meta-reflections on discourses about populism, whilst producing valuable insights, themselves add yet another layer to the ever-expanding body of work on populism and feed off and contribute to the continued focus on populism (the present article obviously does not escape this logic).

For this reason, we need to consider a more strident claim that urges researchers to abandon populism studies as such. The performative role that populism studies - with its journals, conferences, special issues, and so on - plays in reifying populism as a phenomenon per se and as a dominant analytical framework seems inescapable. Similar arguments about reification risks of course apply also to other sub-fields of political and social analysis, from gender studies to nationalism studies. Still, we feel that populism is particularly unsuited to serve as the central nucleus of a field of study.

Allowing ourselves a rather forced adaptation of Yeats' famous words, we could say that in populism studies 'the centre cannot hold'. In other words: in our view, the populist dimension of politics alone (and the minimal definitions that best capture this dimension) - cannot and, indeed, should not - sustain a field of research called populism studies. We are not saying here that the populist dimension of politics does not merit continued systematic and comparative attention, nor are we questioning the significant benefits of the intensification of theoretical work on populism in the last decade or more. Our sense, rather, is that this moment of intensification has lasted long enough, that the most important gains of focusing on populism have been made, in terms of conceptual precision as well as normative nuance, and that these gains no longer outweigh the limitations and negative effects of organizing academic work (and public debate) around populism. This question has particular relevance for discourse theory because, while discourse theorists have a continuing role to play in the study of the populist dimension of politics, there is sometimes the risk that discourse theory becomes identified with the study of populism itself.

More generally, however, it seems time to move resources to other topics than populism or, at the very least, to different angles of approach. It would be fruitful, we believe, to move away more radically from the organization of academic analysis and debate around the nucleus of populism. Even for work that remains interested in populism, this would imply more thoroughly (re)embedding reflections on populism into fields of research focused either on broader questions about, to name the most obvious ones, party systems and the nature of political representation and identification, or media and political communication, or into fields organized around 'thicker' ideological traditions (the radical right, the radical left) as indeed, some of the best work on populism already does. 
The call to move beyond populism studies, then, is a call not just to move beyond the reifications of populism in the study of populism but also a broader call to move beyond the reification risks associated with academia's populist moment, as most clearly embodied in the idea of populism studies. This implies understanding the analysis of populism as something that belongs not to populism studies but to the study of something else, in which populism and discourses about populism play a particular role. It implies linking the interest in populism to broader questions, and embedding the concept and signifier of populism in broader frameworks if and when it helps to unpack particular phenomena and answer particular questions (and only then).

\section{Acknowledgments}

This article has benefited much from the input of the anonymous reviewers as well as several other colleagues at different stages of its development. We would like to thank Arthur Borriello, Nico Carpentier, Péter Csigó, Jonathan Dean, Ryan Flitcroft, Michael Freeden, Anton Jäger, Bice Maiguashca, Aurelien Mondon, Sean Phelan, Bram Spruyt, Yannis Stavrakakis, and Marie Tuley

\section{References}

Akkerman, Tjitske, Cas Mudde, and Andrej Zaslove. 2014. "How Populist are the People? Measuring Populist Attitudes in Voters." Comparative Political Studies 47 (9): 1324-1353.

doi: $10.1177 / 0010414013512600$

Akkerman, Tjitske. 2017. "Populism is overrated - if there is a threat to democacy, it's from authoritarian nationalism." 31 July 2017. http://blogs.lse.ac.uk/europpblog/2017/07/31/populism-isoverrated-if-there-is-a-threat-to-democracy-its-from-authoritarian-nationalism/

Anastasiou, Michaelangelo. 2019. "Of Nation and People: The Discursive Logic of Nationalist Populism.” Javnost - The Public 26 (3): 330-45. doi: 10.1080/13183222.2019.1606562.

Cannon, Barry. 2018. "Must We Talk about Populism? Interrogating Populism's Conceptual Utility in a Context of Crisis." New Political Science 40 (3): 477-96.

doi: 10.1080/07393148.2018.1487187.

Csigó, Péter. 2016. The Neo-Popular Bubble. Speculating on the People in Late Modernity. Budapest: CEU Press.

Collovald, Annie. 2004. Le Populisme du FN: Un Dangereux Contresens. Savoir-agir, BellecombeenBauges: Editions du Croquant.

Dean, Jonathan, and Bice Maiguashca. 2020. "Did Somebody Say Populism? Towards a Renewal and Reorientation of Populism Studies." Journal of Political Ideologies 25(1): 11-27.

doi: 10.1080/13569317.2020.1699712kata

De Cleen, Benjamin. 2017. "Populism and nationalism." In Handbook of Populism, edited by Cristóbal Rovira Kaltwasser, Paul Taggart, Paulina Ochoa Espejo and Pierre Ostiguy. Oxford: Oxford University Press: 342-362. 
De Cleen, Benjamin, Jason Glynos, and Aurelien Mondon. 2018. "Critical Research on Populism: Nine Rules of Engagement.” Organization 25 (5): 649-61. doi:

$10.1177 / 1350508418768053$.

De Cleen, Benjamin, Jason Glynos, and Aurelien Mondon. Forthcoming. "Populist Politics and the Politics of 'Populism': The Radical Right in Western Europe." In Populism in Global Perspective A Performative and Discursive Approach, edited by Pierre Ostiguy, Francisco Panizza, and Benjamin Moffitt. London: Routledge.

De Cleen, Benjamin, and Yannis Stavrakakis. 2017. "Distinctions and Articulations. A Discourse-Theoretical Framework for the Study of Populism and Nationalism." Javnost - The Public 24(4): 301-319. doi: 10.1080/13183222.2017.1330083

D’Eramo, Marco 2013. "Populism and the New Oligarchy." New Left Review 82. Retrieved from https://newleftreview.org/issues/II82/articles/marco-d-eramo-populism-and-the-new-oligarchy

Freeden, Michael. 2017. "After the Brexit Referendum: Revisiting Populism as an Ideology." Journal of Political Ideologies 22 (1): 1-11. doi: 0.1080/13569317.2016.1260813.

Glynos, Jason, and Aurelien Mondon. 2016. "The political logic of populist hype: The Case of Right-wing populism's 'meteoric rise' and its relation to the status quo." POPULISMUS Working Paper Series nr. 4. Downloaded from http://www.populismus.gr/wpcontent/uploads/2016/12/WP4-glynos-mondon-final-upload.pdf

Goyvaerts, Jana and Benjamin De Cleen. 2020. "Media, Anti-populist Discourse and the Dynamics of the Populism Debate." In Perspectives on Populism and the Media, ed. By Benjamin Krämer and Christina Holtz-Bacha, 83-108. Baden-Baden: Nomos Verlag.

Jäger, Anton. 2017. "The Semantic Drift: Images of Populism in Post-war American Historiography and Their Relevance for (European) Political Science." Constellations 24 (3): 310 323. doi: $10.1111 / 1467-8675.12308$

Katsambekis, Giorgos. 2017. "The Populist Surge in Post-Democratic Times: Theoretical and Political Challenges.” The Political Quarterly 88 (2): 202-10. doi: 10.1111/1467-923X.12317.

Laclau, Ernesto. 1977. Politics and Ideology in Marxist Theory: Capitalism, Fascism, Populism. London: New Left Books.

Laclau, Ernesto. 2005a. On Populist Reason. London: Verso.

Laclau, Ernesto. 2005b. "Populism: What's in a Name?" In Populism and the Mirror of Democracy, edited by Francisco Panizza, 32-49. London: Verso

Laclau, Ernesto and Chantal Mouffe. 1985. Hegemony and Socialist Strategy. London: Verso.

Maiguashca, Bice. 2019. "Resisting the 'Populist Hype': A Feminist Critique of a Globalising Concept." Review of International Studies, September, 1-18.

doi: 10.1017/S0260210519000299. 
Moffitt, Benjamin. 2017. The Global Rise of Populism: Performance, Political Style, and Representation. Stanford: Stanford University Press.

Mondon, Aurelien. 2017. "Limiting democratic horizons to a nationalist reaction: populism, the radical right and the working class." Javnost - The Public 24(4): 355-374.

doi: $0.1080 / 13183222.2017 .1330085$

Moffitt, Benjamin. 2015. "How to Perform Crisis: A Model for Understanding the Key Role of Crisis in Contemporary Populism." Government and Opposition 50 (2): 189-217.

doi: $10.1017 /$ gov.2014.13

Mouffe, Chantal. 2018. For a Left Populism. London: Verso.

Mudde, Cas (2017a) "Why Nativism, Not Populism, Should be Declared Word of the Year." The Guardian, 7 December 2017.

https://www.theguardian.com/commentisfree/2017/dec/07/cambridge-dictionary-nativism-

populism-word-year

Mudde, Cas. 2017b. "We are Thinking about Populism Wrong. And it's Costing Us." Huffington Post, 20 March 2017. https://www.huffingtonpost.com/entry/populism-wrong cost_us_58cfeb03e4b0be71dcf63e6c

Mudde, Cas, and Cristóbal Rovira Kaltwasser. 2017. Populism: A Very Short Introduction. Oxford: Oxford University Press.

Mudde, Cas, and Cristóbal Rovira Kaltwasser. 2018. "Studying Populism in Comparative Perspective: Reflections on the Contemporary and Future Research Agenda." Comparative Political Studies 51(13): 1667-1693. doi: 10.1177/0010414018789490

Rooduijn, Matthijs. 2019 "State of the field: How to Study Populism and Adjacent Topics? A Plea for Both More and Less Focus." European Journal of Political Research 58(1): 362-372.

doi: 10.1111/1475-6765.12314

Rydgren, Jens. 2017. "Radical Right-Wing Parties in Europe: What's Populism Got to Do with It?” Journal of Language and Politics 16 (4): 485-96. doi: 10.1075/jlp.17024.ryd.

Stavrakakis, Yannis. 2014. "The European Populist Challenge." Annals of the Croatian Political Science Association 10(1): 25-39. https://hrcak.srce.hr/123089

Stavrakakis, Yannis, and Giorgios Katsambekis. 2014. "Left-Wing Populism in the European Periphery: The Case of Syriza.” Journal of Political Ideologies 19 (2): 119-142.

doi: 10.1080/13569317.2014.909266

Stavrakakis, Yannis, Alexandros Kioupkiolis, Giorgos Katsambekis, Thomas Siomos, and Nikos Nikisianis. 2016. "Contemporary Left-wing Populism in Latin America: Leadership, Horizontalism, and Post-democracy in Chávez's Venezuela." Latin American Politics and Society 58 (3): 51-76. doi: 10.1111/j.1548-2456.2016.00318.x

Stavrakakis, Yannis. 2017a. "Discourse Theory in Populism Research: Three Challenges and a Dilemma." Journal of Language and Politics 16 (4): 523-534. doi: 10.1075/jlp.17025.sta 
Stavrakakis, Yannis. 2017b. "How Did Populism Become a Pejorative Concept? And Why is This Important Today? A Genealogy of Double Hermeneutics." POPULISMUS Working Papers No. 6. Available at: http://www.populismus.gr/wpcontent/uploads/2017/04/stavrakakis-populismuswp-6-upload.pdf

Stavrakakis, Yannis, Giorgos Katsambekis, Alexandros Kioupkiolis, Thomas Siomos, and Nikos Nikisianis. 2017. "Extreme right-wing populism in Europe: revisiting a reified association." Critical Discourse Studies 14 (4): 420-439. doi: 10.1080/17405904.2017.1309325

Stavrakakis, Yannis, Giorgos Katsambekis, Alexandros Kioupkiolis, Nikos Nikisianis, and Thomas Siomos. 2018. "Populism, Anti-Populism and Crisis." Contemporary Political Theory 17 (1): 4-27. doi: 10.1057/s41296-017-0142-y.

Thomassen, Lasse. 2016. "Hegemony, Populism and Democracy: Laclau and Mouffe Today (review article)." Revista Española de Ciencia Política 40: 161-76.

Zúquete, José Pedro. 2018. "From Left to Right and Beyond: The Defense of Populism.” In Routledge Handbook of Global Populism, ed. by Carlos de la Torre, 430-448. London: Routledge. 